\title{
Game technologies as a means of increasing the educational motivation of university students
}

\section{Las tecnologías de juego como medio para incrementar la motivación educativa de los estudiantes universitarios}

\author{
Larisa V. Tsyganova \\ Togliatti State University, Togliatti, Russia \\ ORCID: https://orcid.org/0000-0003-2784-9234 \\ Yana V. Zubkova \\ Moscow State University of Civil Engineering, Moscow, Russia \\ ORCID: https://orcid.org/0000-0002-2484-7316 \\ Natalia V. Bystrova \\ Minin Nizhny Novgorod State Pedagogical University, Russia. \\ ORCID: https://orcid.org/0000-0002-4310-6142 \\ Lyubov I. Kutepova \\ Minin Nizhny Novgorod State Pedagogical University, Russia. \\ ORCID: https://orcid.org/0000-0002-3175-4978 \\ Maxim M. Kutepov \\ Minin Nizhny Novgorod State Pedagogical University, Russia. \\ ORCID: https://orcid.org/0000-0002-5397-6168
}

Received 07-12-20 Revised 08-25-20

Accepted 10-13-20 On line 12-12-20

*Correspondence

Email: ivannovadremova29@gmail.com
Cite as:

Tsyganova, L., Zubkova, Y., Bystrova, N., Kutepova, L., Kutepov, M. (2021). Game technologies as a means of increasing the educational motivation of university students. Propósitos y Representaciones, 9 (SPE1), e808. Doi: http://dx.doi.org/10.20511/pyr2021.v9nSPE1.e808 


\section{Summary}

Game technologies allow bringing the educational process as close as possible to professional activities, activating the cognitive interest of students in the study of professional disciplines. The purpose of the article is to analyze the experience of implementing gaming technologies in the preparation of students of higher educational institutions to increase their motivation for learning. Game technologies are a set of methods and techniques for organizing the educational process in the form of various games that stimulate cognitive activity. They allow you to simulate a real workflow and consolidate theoretical material. Motivation is defined as a set of internal motivations that explain the student's behavior, orientation and activity in the educational process. Motivation acts as a continuous choice and decision-making based on weighing behavioral alternatives. The article presents a study of the impact of gaming technology on changing students' motivation. As a tool for the study of motivation, we used Dubovitskaya methodology for the diagnosis of motivation. The study reflects the impact of gaming technology on changing student motivation. The implementation of gaming technologies in the training of students of a higher educational institution helps to increase the motivation of students to study professional disciplines, the formation of professional competence.

Key Words: competence, educational motivation, game technology, professional education, professional competence, professional preparation.

\section{Resumen}

Las tecnologías de juego permiten acercar al máximo el proceso educativo a las actividades profesionales, activando el interés cognitivo de los estudiantes por el estudio de disciplinas profesionales. El propósito del artículo es analizar la experiencia de implementar tecnologías de juego en la preparación de estudiantes de instituciones de educación superior para aumentar su motivación por el aprendizaje. Las tecnologías de juego son un conjunto de métodos y técnicas para organizar el proceso educativo en forma de varios juegos que estimulan la actividad cognitiva. Te permiten simular un flujo de trabajo real y consolidar material teórico. La motivación se define como un conjunto de motivaciones internas que explican el comportamiento, orientación y actividad del alumno en el proceso educativo. La motivación actúa como una elección y una toma de decisiones continuas basadas en la ponderación de alternativas de comportamiento. El artículo presenta un estudio del impacto de la tecnología de los juegos en el cambio de motivación de los estudiantes. Como herramienta para el estudio de la motivación, utilizamos la metodología Dubovitskaya para el diagnóstico de la motivación. El estudio refleja el impacto de la tecnología de los juegos en el cambio de motivación de los estudiantes. La implementación de tecnologías de juego en la formación de estudiantes de una institución de educación superior ayuda a aumentar la motivación de los estudiantes para estudiar disciplinas profesionales, la formación de competencias profesionales.

Palabras clave: competencia, motivación educativa, tecnología de juegos, educación profesional, competencia profesional, preparación profesional.

\section{Introducción}

In modern conditions of professional education development, it becomes important to form the competence of the student's personality, which has the appropriate structure of the needmotivational sphere (Vaskovskaya, 2018). The success of the formation of the student's competence and competitiveness in the labor market depends on the activity of the student (Tolkanuk, 2019). Modern regulatory documents indicate the need to use innovative educational technologies in the educational process that provide increased motivation for students (Vaganova et al., 2019b). The article reveals the experience of implementing game technologies in the educational process to increase motivation. 
In the course of professional training, business and role-playing games are implemented that ensure students ' initiative and involvement in the process (Oros, 2018).

Business and role-playing games are a special type of organization of collective cognitive activity of students (Aleksieienko-Lemovska, 2019).

The business game is a form of recreating the subject and social content of a specialist's future activity (Tsarapkina et al., 2019b), modeling a certain system of relations characteristic of this activity (Andriushchenko, 2018).

In the game, participants are interconnected and interdependent (Klinkov, 2018). They build relationships based on business cooperation (Cirdan, 2019).

Role-playing involves a problem situation and a certain number of characters with assigned functions and roles (Kobernyk et al., 2018).

Game conditions encourage students to actively interact and independently search for information to solve a certain range of problems (Halatsyn \& Feshchuk, 2019). In this process, the student begins to realize the importance of professional activity, to reveal their creative potential, has the opportunity to expand independent activities and increase the level of motivation (Prokhorova \& Semchenko, 2018).

\section{Theoretical framework}

The concept and main aspects of the development of educational motivation are considered by $\mathrm{L}$. I. Bozhovich, I. A. Kotlyar (Kotlyar, 2008), A. A. Verbitsky, Yu.M. Orlova, I. F. Isaeva and others. The influence of students ' motivation is presented in the works of A.V. Mudrik, A.V. Gladkov (Gladkov et al., 2019), G. A. Pichugina (Pichugina \& Zhilyakova, 2019), I. F. Filchenkova (Filchenkova, 2019) and others. E. A. Klimov, A. N. Ovcharenko, and O. Yu. Donetskova (Donetskova, 2019) were engaged in the formation of motivation in educational and professional activities. The works of V. A. Orlov, N. E. are devoted to the topic of motivation activation. Titovoi, V. G. tretyaka, O. A. Andrienko (Andrienko, 2019a). The ideas of introducing game technologies in the training of specialists in higher education are considered by A. A. Smolentseva, A. A. Orlov, A.V. Khutorsky and other researchers. Justification of the business game as a means of forming professional competence is revealed in the works of E. Belchikov, L. I. Kryukova, M. N. Kuzmina and others. However, the issue of implementing game technologies that influence the development of educational motivation of students at all stages of training remains not fully studied (Rojas et al, 2017).

Educational motivation consists of a student's assessment of various aspects of the learning process, its content, forms and methods of organization in terms of their individual needs and goals, which may or may not coincide with the learning goals. Motivation can be interpreted as:

- a set of motives that cause human activity (a system of factors that determine the behavior of an individual, that is, a set of needs, motives, goals, intentions, aspirations);

- the process of formation of motives that stimulate and support behavioral activity at the appropriate level.

Motivation is also a set of reasons that explain a person's behavior, orientation, and activity (Raven, 2017). Any form of behavior is caused by both internal and external factors (Bakhareva, 2019). Internal factors include goals, intentions, desires, and interests (Chertovskikh, 2019).

External factors come from incentives generated by certain conditions. 
Motivation manifests itself in the process of continuous choice and decision-making based on the weighing of behavioral alternatives that the student selects by the playing conditions, functions and roles inherent in a particular type of game (Vaganova et al., 2019a).

Motivation explains the purposefulness of actions, the integrity and organization of activities aimed at achieving certain goals.

There are two types of motivations:

- external (caused by external circumstances for a person, not related to activity) (Pisarenko, 2019);

- external positive motivation is based on positive incentives, related to the satisfaction of external needs (for example, prestige, respect);

- external negative motivation is focused on the implementation of self-defense, is situational and adaptive-uncertain;

- internal (related to the content of the activity, but not to external circumstances).

The implementation of game technologies that activate the subject position of students helps to increase motivation to study.

Among the principles of implementing business and role-playing games to increase students' motivation are:

- the principle of problematic content of the game;

- the principle of simulation of specific conditions and dynamics of changes in situations (Petrichev et al., 2018);

- the principle of joint activity (Pliushch, 2018);

- the principle of dialogical communication (Vaganova et al., 2019c).

Within the game, certain conditions are met that contribute to achieving the set goals. These conditions include information technology, material and technical support, personal and activity readiness of students. The development of motivation through gaming technologies involves the inclusion of modern information, communication technologies and technical resources (Grigoriev et al., 2019).

\section{Methodology}

Game educational technologies (business, role-playing games, etc.) were implemented in the organization of the educational process. Students of higher education institutions took part in the study of motivation in 2018 and 2019.

The method implemented in the study by T. D. Dubovitskaya is a set of 25 judgments that students need to agree or disagree with. Data processing is performed on four scales: "Attitude to the profession"; "External positive motivation";" External negative motivation"; "Internal motivation".

The reliability test was performed using the "splitting" method and the subsequent calculation of the corresponding coefficients.

The test of constructive validity was carried out using motivation scales and consisted in calculating the correlation coefficients of the total results obtained using this method.

The questionnaire indicators are calculated according to the key, where "Yes" or " + "means a positive answer (Yes; more likely Yes than no)," No" or "-" means a negative answer (no, more likely no than Yes). A key is provided for each response. 1 point is awarded for matching 
the student's response with the key. The higher the total score, the higher the motivation of students. The questionnaire fragment is shown in table 1.

Table 1.

Diagnostic methodology for students' learning motivation (Dubovitskaya T. D.)

\begin{tabular}{|c|c|c|c|c|c|}
\hline No. & Question & \multicolumn{4}{|c|}{ Answers } \\
\hline 1 & $\begin{array}{l}\text { You have chosen the direction of training at a } \\
\text { higher educational institution independently and } \\
\text { consciously }\end{array}$ & Yes & $\begin{array}{l}\text { Rather } \\
\text { yes than } \\
\text { no }\end{array}$ & No & $\begin{array}{l}\text { More } \\
\text { likely no } \\
\text { than yes }\end{array}$ \\
\hline 2 & $\begin{array}{l}\text { Becoming a highly qualified specialist in your } \\
\text { chosen field is one of the most important goals in } \\
\text { your life. }\end{array}$ & Yes & $\begin{array}{l}\text { Rather } \\
\text { yes than } \\
\text { no }\end{array}$ & No & $\begin{array}{l}\text { More } \\
\text { likely no } \\
\text { than yes }\end{array}$ \\
\hline 3 & $\begin{array}{l}\text { The studied professional disciplines are interesting } \\
\text { to me, I strive to deepen my knowledge and } \\
\text { experience in this field }\end{array}$ & Yes & $\begin{array}{l}\text { Rather } \\
\text { yes than } \\
\text { no }\end{array}$ & No & $\begin{array}{l}\text { More } \\
\text { likely no } \\
\text { than yes }\end{array}$ \\
\hline 4 & $\begin{array}{l}\text { Encountered difficulties while studying of } \\
\text { professional disciplines often stop me }\end{array}$ & Yes & $\begin{array}{l}\text { Rather } \\
\text { yes than } \\
\text { no }\end{array}$ & No & $\begin{array}{l}\text { More } \\
\text { likely no } \\
\text { than yes }\end{array}$ \\
\hline 5 & $\begin{array}{l}\text { Studying professional disciplines allows me to } \\
\text { fulfill my potential }\end{array}$ & Yes & $\begin{array}{l}\text { Rather } \\
\text { yes than } \\
\text { no }\end{array}$ & No & $\begin{array}{l}\text { More } \\
\text { likely no } \\
\text { than yes }\end{array}$ \\
\hline 6 & $\begin{array}{l}\text { You are ready to realize yourself in the chosen } \\
\text { professional activity }\end{array}$ & Yes & $\begin{array}{l}\text { Rather } \\
\text { yes than } \\
\text { no }\end{array}$ & No & $\begin{array}{l}\text { More } \\
\text { likely no } \\
\text { than yes }\end{array}$ \\
\hline 7 & $\begin{array}{l}\text { You seek to acquire professionally significant } \\
\text { skills. }\end{array}$ & Yes & $\begin{array}{l}\text { Rather } \\
\text { yes than } \\
\text { no }\end{array}$ & No & $\begin{array}{l}\text { More } \\
\text { likely no } \\
\text { than yes }\end{array}$ \\
\hline 8 & $\begin{array}{l}\text { You need a creative search for ways and means of } \\
\text { self-realization }\end{array}$ & Yes & $\begin{array}{l}\text { Rather } \\
\text { yes than } \\
\text { no }\end{array}$ & No & $\begin{array}{l}\text { More } \\
\text { likely no } \\
\text { than yes }\end{array}$ \\
\hline
\end{tabular}

The results obtained during response processing were interpreted as follows:

- 0 -10 points-external motivation;

- 11-20 points-internal motivation.

used:

To determine the level of internal motivation, the following normative boundaries were

- $\quad 0-5$ points - low level of internal motivation;

- 6-14 points-average level of internal motivation;

- 15-20 points - a high level of internal motivation.

We measured the level of the type of motivation that was found in the majority of students at the first stage of the study. Motivation levels are characterized by the student's desire to study professional disciplines, to reveal the personal potential in future professional activities, and to participate in various professional games, competitions, and seminars (Arbeláez-Campillo, \& Rojas-Bahamon, 2020).

The methodology for evaluating motivation includes an assessment of the type of distribution of raw points, the degree of its approximation to the normal distribution. The internal reliability of parts of the method was evaluated using Cronbach's coefficient. In order to develop 
standards for evaluating statements that constitute educational motivation, the method was tested on a study group of students before the study.

\section{Results and discussion}

During the course of the study, students participated in various business and role-playing games throughout the year. Games are dedicated to both individual aspects of professional activity and broader processes.

For example, the business game "Assigning a task to a subordinate" involves subordinates and managers. Acting managers think through the task and choose the official to whom it will be assigned. The content of the business conversation includes: explaining the task and instructing the subordinate, bringing the task to the stage of understanding its essence by the subordinate, motivating the subordinate to perform the task efficiently.

In the course of a business conversation, to make the right decision, the Manager must find out a few questions for himself: whether a particular subordinate will be able to complete the task, whether they are motivated to complete the task, and what kind of instruction they need. The subordinate takes the position of refusing to perform the task, where the argument is insufficient competence. This setting allows the " Manager "to improve the techniques of influence on the" subordinate", forming his readiness to perform the task. A business conversation requires preliminary preparation. The student needs to think through the purpose of the upcoming conversation, the conversation plan and organizational conditions and prepare questions for the "subordinate".

Observers of the conversation are given the opportunity to evaluate it according to the criteria or questions developed by the teacher and identify its quality. For example, " Did the head clearly formulate the questions?"," was the instruction on the task conducted Correctly?", "Did the head listen to all the arguments?".

The role-playing game is conducted as part of the entire group of students, whose members are divided into managers, legal department, and department for financial and economic issues. Each participant has its own role. Each of the departments is engaged in the implementation of the project, which will be discussed at the final meeting. The host of the game reminds us that the preparation of meetings involves several main groups of actions: planning the meeting, setting the agenda, determining the composition of participants, preparing them for the meeting, preparing managers, and directly conducting the meeting. In the process of project preparation, departments compete with each other, which allows creating effective competition that leads to the rapid achievement of results.

Students are introduced to various methods of research, the organization of the team, the functions of future professional activities.

Figure 1 shows the results of data processing to identify the type of motivation of students. 


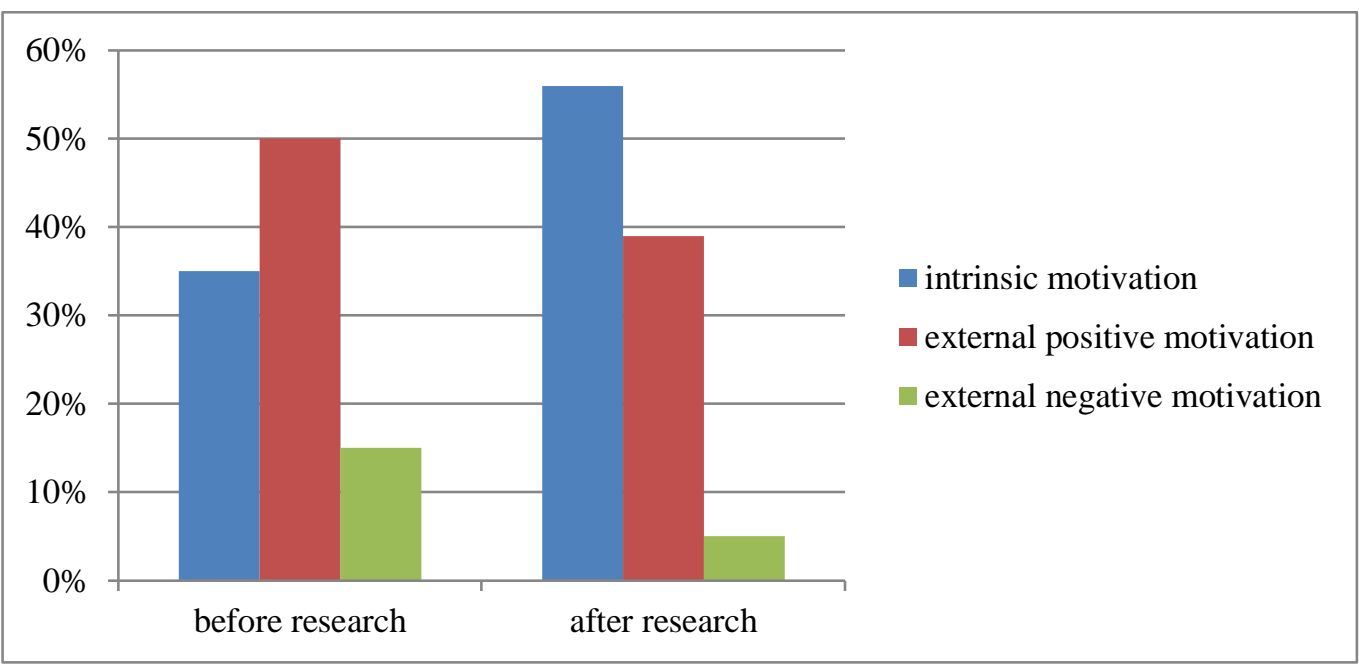

Fig. 1. Results of diagnostics of internal and external students' motivation before and after the study (as part of our study)

Before the professional business and role-playing games in 2018, students' external positive motivation prevailed, i.e. they focused on external factors that encourage them to study professional disciplines. After the study was conducted in 2019, internal motivation began to prevail, which indicates the formation of ideas about future professional activity and awareness of its implementation. During the research, through the implementation of business and role-playing games, we were able to involve each participant in an active learning process.

Figure 2 shows the results of data processing to identify the level of motivation of students.

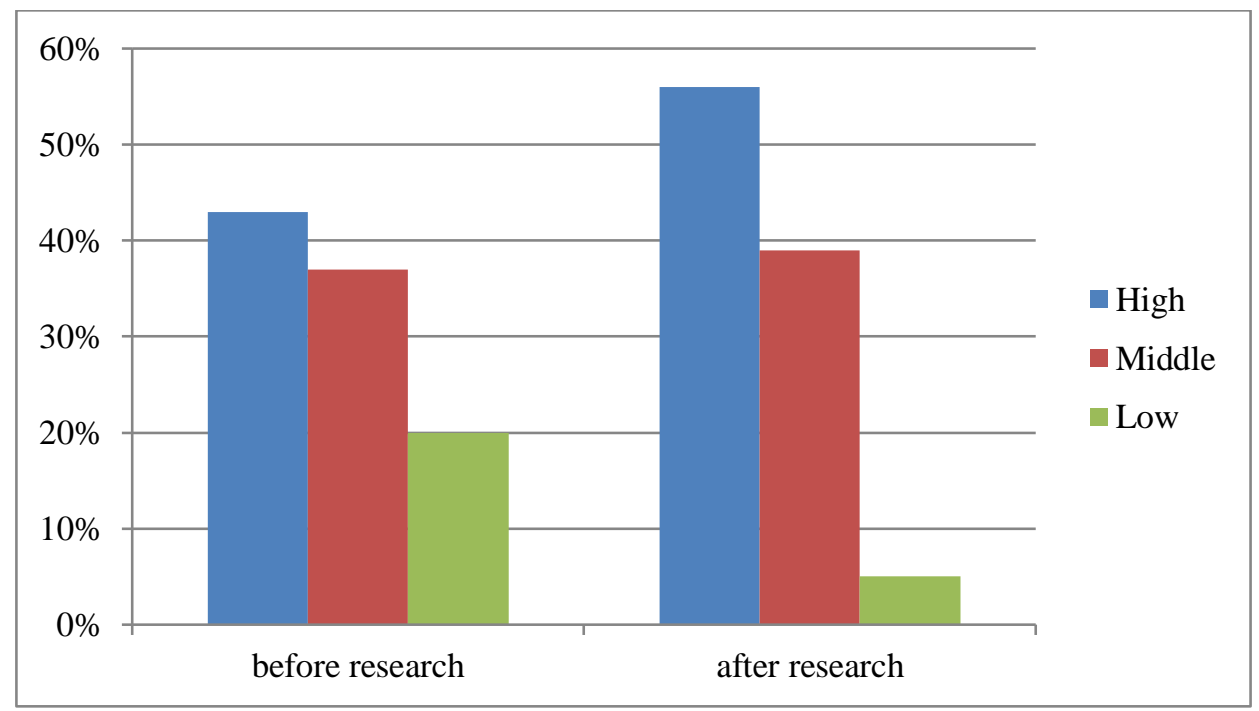

Fig. 2. Results of diagnostics of the level of students' educational motivation (as part of our study)

During the study, we managed to increase the number of students with a high level of motivation from $43 \%$ to $56 \%$. The average level of motivation has become $39 \%$ of students. 


\section{Conclusions}

Analysis of the experience of implementing game technologies in the training of students of higher educational institutions has shown that game technologies have high cognitive efficiency, providing motivation for students based on the principles of collective interaction, transparency, competition, unlimited prospects for creative activity. Games are of particular interest to students due to the creation of conditions close to professional ones. The process of implementing game technologies is characterized by emotional saturation. The learning process becomes more active. It includes all students since each of them performs a certain function and contributes to the achievement of the result.

With the introduction and implementation of business and role-playing games in the educational process, external motivation due to the impact of the environment, the desire to get a high score is replaced by internal - due to interest in future professional activities, the desire to study the material in depth.

Increasing the level and quality of motivation improves the quality of professional training results.

Conflict of interests: The authors declare that they have no conflicts of interest.

Authors' contribution: The authors have participated in the research process, in the writing of the work and in the analysis of the documents.

\section{Bibliographic references}

Aleksieienko-Lemovska, L.V. (2019). The activity approach as a basis for preschool teachers' methodological activities. Humanitarian Balkan Research, 3, 4(6), 10-14.

Andrienko, O.A. (2019a). On the need to apply gaming training technologies. Balkan Scientific Review, 2(4), 5-8.

Andrienko, O.A. (2019b). Modern educational technologies: technology of self-presentation. Balkan Scientific Review, 1(3), 5-7.

Andriushchenko, T. K. (2018). Personal aspects of pedagogue's innovative culture, Scientific Vector of the Balkans, 1, 13-16.

Arbeláez-Campillo, D.F., \& Rojas-Bahamon, M.J (2020). "Pandemics in globalization times". Amazonia Investiga, $9(27), \quad 3-4$. https://amazoniainvestiga.info/index.php/amazonia/article/view/1189

Bakharev, N. P. (2019). Creativity - a prerequisite for the formation of professional competences in specialists of technical direction of training. Scientific Vector of the Balkans, 3, 4(6), 17-21.

Chertovskikh, O.O. (2019). Prospects for the use of digital resources in education. Baltic Humanitarian Journal. 8, 4(29), 184-187.

Cirdan, A.P. (2019). Innovative technologies of professional training of future economists in the system of continuous education. Humanitarian Balkan Research, 2(4), 27-30.

Donetskova, O.YU. (2019). Modernization of the modern education system in Russia. Baltic Humanitarian Journal, 8, 2(27), 37-39. 
Filchenkova, I.F. (2019). Educational management of innovative activity of teachers as an object of pedagogical research. Vestnik of Minin University, 7(4), 3.

Gladkov, A.V., Vaganova, O.I., \& Prokhorova, M.P. (2019). Modern pedagogical technologies as a means of enhancing educational motivation. Baltic Humanitarian Journal, 8, 1(26). 274276.

Grigoriev, S. G., Shabunina, V. A., Tsarapkina, Ju. M., \& Dunaeva, N. V. (2019). Electronic library system as a means of self-development of students of digital generation $\mathrm{Z}$ (on the example of studying the course "Basics of the counselor activity"). Scientific and technical libraries, 7, 78-99. 29.

Halatsyn, K.A., \& Feshchuk, A.M. (2019). Diagnosing motivational-and-valuable component of the communicative culture of students in higher technical educational institutions. Balkan Scientific Review, 3, 2(4), 17-20.

Klinkov, G.T. (2018). The specificity of manifestation of pedagogical communication as a special construct. Scientific Vector of the Balkans, 1, 51-52.

Kobernyk, O.M., Stetsenko, N.M., Boichenko, V.V., \& Pryshchepa, S.M. (2018). Improving professional and pedagogical training of future teachers by moodle platforms (On the example of the course "Pedagogy"). Scientific Vector of the Balkans, 1, 5-7.

Kotlyar, I.A. (2008). About the early studies of L.I. Bozhovich. Modern problems of personality psychology: theory and practice.

Lednev, V.S. (1991). he content of education: essence, structure, perspectives (2nd ed. Revised), M.: Vyssh. shk., 224.

Lerner, I. Ya. (1978). The composition of the content of education and the ways of its implementation in the textbook. In the book. School textbook problems. M.: Prosveshcheniye, 6, 46-64.

Oros, I.I. (2018) The role of international connections in the development of the adult education system. Humanitarian Balkan Research, 1, 57-59.

Osadchenko, I.I. (2019). Key concepts of situational training technology in preparing future teachers. Scientific Vector of the Balkans, 1(3), 46-49.

Petrichev, P. V., Masyuk, N. N., \& Bushueva, M. A. (2018). Method of estimation of the effectiveness of the partnership russian universities with foreign educational organizations. Azimuth of Scientific Researches: Economics and Management, 7, 3(24), 229-232.

Pichugina, G. A., \& Zhilyakova, D. A. (2019) Structuring the organization of the process of creativity. Scientific Vector of the Balkans, 3, 3(5), 55-58.

Pisarenko, D. A. (2019). Evaluation of extracurricular activities of university students with a competency-based approach. Scientific Vector of the Balkans, 3, 3(5), 37-40.

Pliushch, V.M. (2018). Independent work of students as a factor of improving education quality. Balkan Scientific Review, 1, 69-71. 
Prokhorova, M.P., \& Semchenko, A.A. (2018). Involving of trainees-future teachers of professional training in project activities in the discipline. Vestnik of Minin University, $6(2), 6$.

Raven, J. (2017). Education and Sociocybernetics. Azimuth of Scientific Researches: Economics and Management, 6, 3(20), 289-297.

Rojas, M.J., López de Parra, M.L., Arbeláez, D.F., y Correa, L. (2017) "Rendimiento académico en estudiantes de secundaria según asignaturas, estrato socioeconómico y su contacto con el conflicto armado en Colombia" Revista Latinoamericana de Estudios Educativos, XLVII (3-4), 155-172. https://www.redalyc.org/pdf/270/27054113006.pdf

Sokhor, A.M. (1974). The logical structure of the educational material. Questions of didactic analysis. Pedagogika, 192.

Tolkanuk, Z. A. (2019). Professional self-determination of youth as a factor of training of a competent specialist. Balkan Scientific Review, 3, 2(4), 57-59.

Tsarapkina, Ju. M., Dunaeva, N. V., \& Kireicheva, A. M. (2019b). Application of BYOD technology in education on the example of Lecture Racing mobile application, Informatics and Education, 9(308), 56-64.

Tsarapkina, Ju.M., Petrova, M.M., Mironov, A.G., Morozova, I.M., \& Shustova, O.B. (2019a). Robotics as a basis for Informatization of education in children's health camp. Amazonia Investiga, $8(20)$. $115-123$ https://www.amazoniainvestiga.info/index.php/amazonia/article/view/70

Vaganova, O.I., Ilyashenko, L.I., Smirnova, Zh.V., Bystrova, N.V., \& Kaznacheeva, S.N. (2019a). Students' creative abilities development in higher educational institution. Amazonia Investiga, $8(22)$ 701-710 https://www.amazoniainvestiga.info/index.php/amazonia/article/view/822

Vaganova, O.I., Livshits, Yu.A., Aleshugina, E.A., Smirnova, Zh.V., \& Kutepova, L.I. (2019c). Experience in developing electronic glossary in a higher education institution. Amazonia Investiga, $8(22)$, https://www.amazoniainvestiga.info/index.php/amazonia/article/view/421

Vaganova, O.I., Rudenko, I.V., Markova, S.M., Smirnova, Zh.V., \& Kutepov, M.M. (2019b). The use of educational video materials in educational process of a higher educational institution. Amazonia Investiga, 8(22), 216-222. https://www.amazoniainvestiga.info/index.php/amazonia/article/view/308

Vaskovskaya, G.A. (2018). Features of implementation of pedagogical technologies of profile training. Balkan Scientific Review, 1, 76-79. 